\title{
A case report of lead fracture presenting as high ventricular premature complex burden
}

Saurabh Deshpande ${ }^{1}$ and Ameya Udyavar ${ }^{2}$

${ }^{1}$ Western Railway Jagjivan Ram Hospital Mumbai

${ }^{2}$ PD Hinduja National Hospital and Medical Research Centre

June 22, 2021

\section{Hosted file}

DDD pacemaker JCE.docx available at https://authorea.com/users/420983/articles/527169-a-casereport-of-lead-fracture-presenting-as-high-ventricular-premature-complex-burden
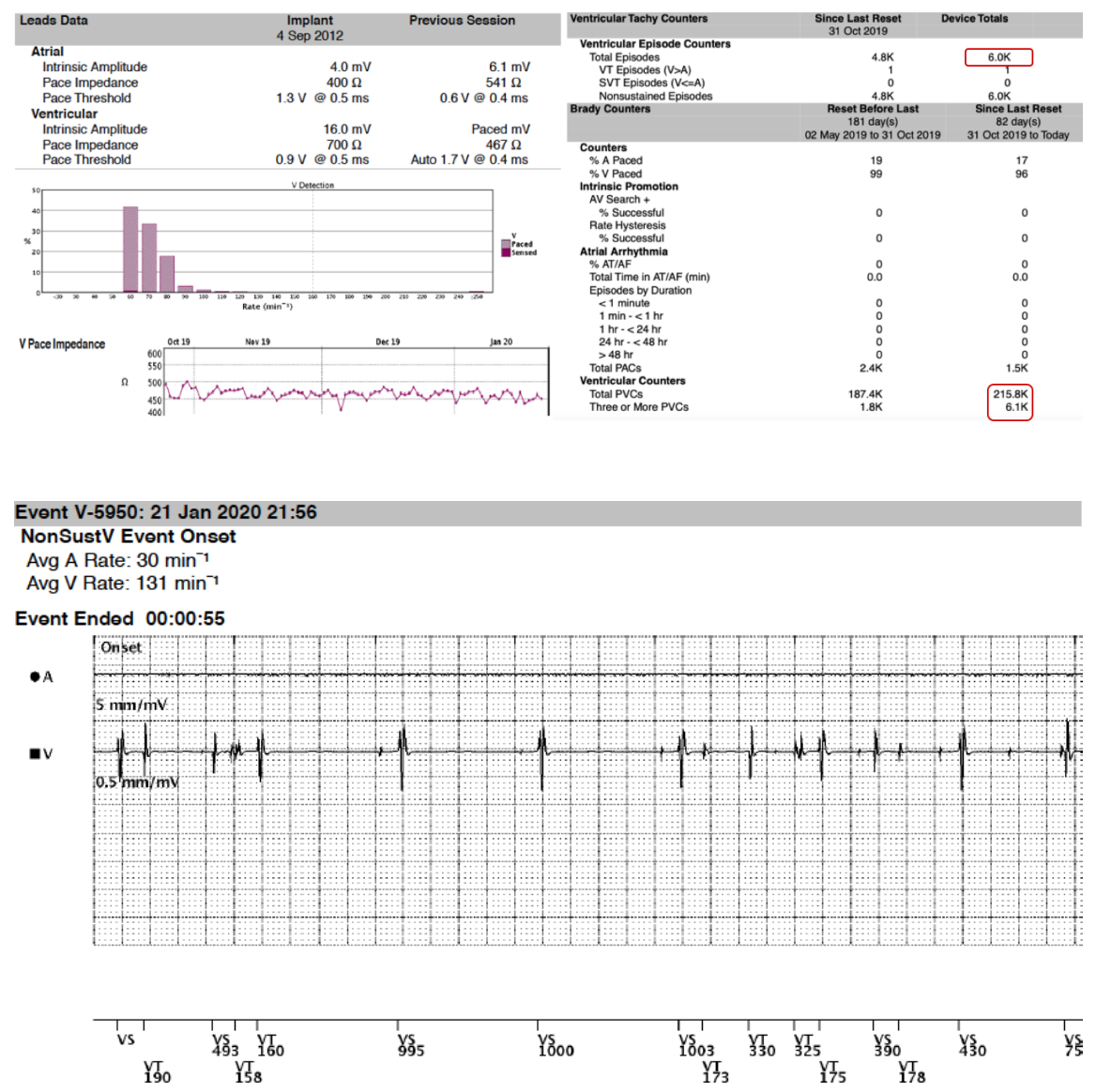

\section{Hosted file}


Tables.docx available at https://authorea.com/users/420983/articles/527169-a-case-report-oflead-fracture-presenting-as-high-ventricular-premature-complex-burden 